УДК 66.066

\title{
ВПЛИВ ЧАСТОТИ КОЛИВАНЬ ЕЛЕКТРИЧНОГО ПОЛЯ НА ПРОЦЕС КОАЛЕСЦЕНЦІЇ ВОДИ В РОБОЧІЙ РІДИНІ
}

\author{
Канд. техн. наук С.В. Воронін, асп. І.Ю. Сафонюк, магістрант А.В. Олійник
ВЛИЯНИЕ ЧАСТОТЫ КОЛЕБАНИЙ ЭЛЕКТРИЧЕСКОГО ПОЛЯ НА ПРОЦЕСС КОАЛЕСЦЕНЦИИ ВОДЫ В РАБОЧЕЙ ЖИДКОСТИ

Канд. техн. наук С.В. Воронин, асп. И.Ю. Сафонюк, магистр А.В. Олейник

\section{EFFECT FREQUENCY VIBRATIONS OF ELECTRIC FIELD ON THE PROCESS WATER COALESCENCE IN THE WORKING FLUID}

\author{
Cand. of techn. sciences C. Voronin, postgraduate student I. Safonyuk,
} master student A. Oliyinik

Наведені результати експериментальних досліджень процесу коалесценції води в індустріальній оливі під дією змінного електричного поля. Встановлена залежність часу освітлення оливи від частоти поля.

Ключові слова: емульсія, вода, час освітлення, коалесценція, седиментація, електричне поле, частота.

Приведень результаты экспериментальных исследований прочесса коалесценции водьы в индустриальном масле под действием переменного электрического поля. Установлена зависимость времени осветления масла от частоты поля.

Ключевые слова: эмульсия, вода, время осветления, коалесиенция, седиментация, электрическое поле, частота.

The paper presents the results of experimental studies of the process of coalescence of water in industrial oils under the influence of an alternating electric field. Dependence of light oil on the frequency of the electric field is established. Maintaining the desired purity of the working fluid is an important factor in the reliability of transmissions. One of the common pollutants fluids is water. Water in the oil is dispersed in the state. The most slowly deposited droplets with a diameter of about 5 microns. However, the process of settling water can be affected by treatment in an electric field. The reason for this is large difference of dielectric dispersion phases. The experimental data can be used to develop an electrical method of cleaning fluid for hydraulic machinery and other petroleum-based oils. The key issue is to achieve maximum performance purification process.

Keywords: emulsion, water, time lighting, coalescence, sedimentation, electric field frequency.

Вступ. Підтримка заданої чистоти робочої рідини (РР) є важливим фактором надійності гідропривода. Одним із поширених забруднювачів РP $\epsilon$ вода. Така вода може перебувати у вільному стані, розчиненому (знаходитись в колоїдному стані за рахунок полярних зв'язків) або бути емульсованою (желеподібний стан), яка не відстоюється та призводить до утворення гідроген-водневих фракцій, корозії металічних елементів гідропривода, окислення РР, підвищення спінювання та погіршення дії присадок, що в свою чергу призводить до пришвидшеного зносу [1].

Найбільш поширеними методами відділення води від нафтових олив $\epsilon$ 
центрифугування, випаровування води, відстоювання, відділення за допомогою адсорбуючих полімерів. Однак ці методи не завжди $\epsilon$ ефективними [2], оскільки вони мають або низьку продуктивність, або високу енергоємність та вартість.

Постановка проблеми. РР гідропривода являє собою неполярний діелектрик 3 відносною діелектричною проникністю $2 \ldots 3$, в якій розчинений сильно полярний діелектрик - вода, діелектрична проникність якої в 40 разів вища. Така суттєва різниця між властивостями РP і води надає підстави для дослідження та розроблення електричних методів очищення РP.

При застосуванні електричних методів потрібно проводити дослідження, спрямовані на визначення раціональних параметрів електричного поля, при яких процес видалення води з РР буде максимально ефективним, тобто коли має місце висока продуктивність процесу, висока тонкість очищення та малі енерговитрати.

\section{Аналіз останніх досліджень i} публікацій. Процес злиття крапель дисперсної системи (системи, яка складається із фаз, які не змішуються і не реагують хімічно між собою) називається коалесценцією. Коалесценція води в зовнішньому електричному полі досліджувалася вітчизняними вченими ще в 50-x - 60-х роках [3,4]. 3 тих пір цей процес застосовується в нафтопереробній галузі, однак вплив фактора чистоти в середовищі оливи не досліджувався.

Головним завданням при очищенні оливи від води $\epsilon$ видалення крапель розміром менше 5 мкм. На такі краплі міра діï Броунівських сил перевищує дію гравітаційних сил, що унеможливлює їх осідання. В такому випадку, щоб покращити седиментацію (осідання часток дисперсної фази під дією гравітаційного поля) води в оливі, необхідно створити умови для об'єднання цих капель у більш великі. Якщо для об'єднання крапель необхідний їхній безпосередній контакт, то основною умовою ефективного укрупнення є:

$$
A \geq D-d,
$$

де $A$ - амплітуда коливань краплі;

$D$ - відстань між випадковими сусідніми краплями;

$d$ - діаметр краплі.

Відстань між краплями (рис. 1) залежить від концентрації води в оливі та міри дисперсності. Амплітуда коливань, в свою чергу, - від геометричних розмірів крапель, в'язкості, густини та параметрів зовнішнього електричного поля, а саме напруженості та частоти.

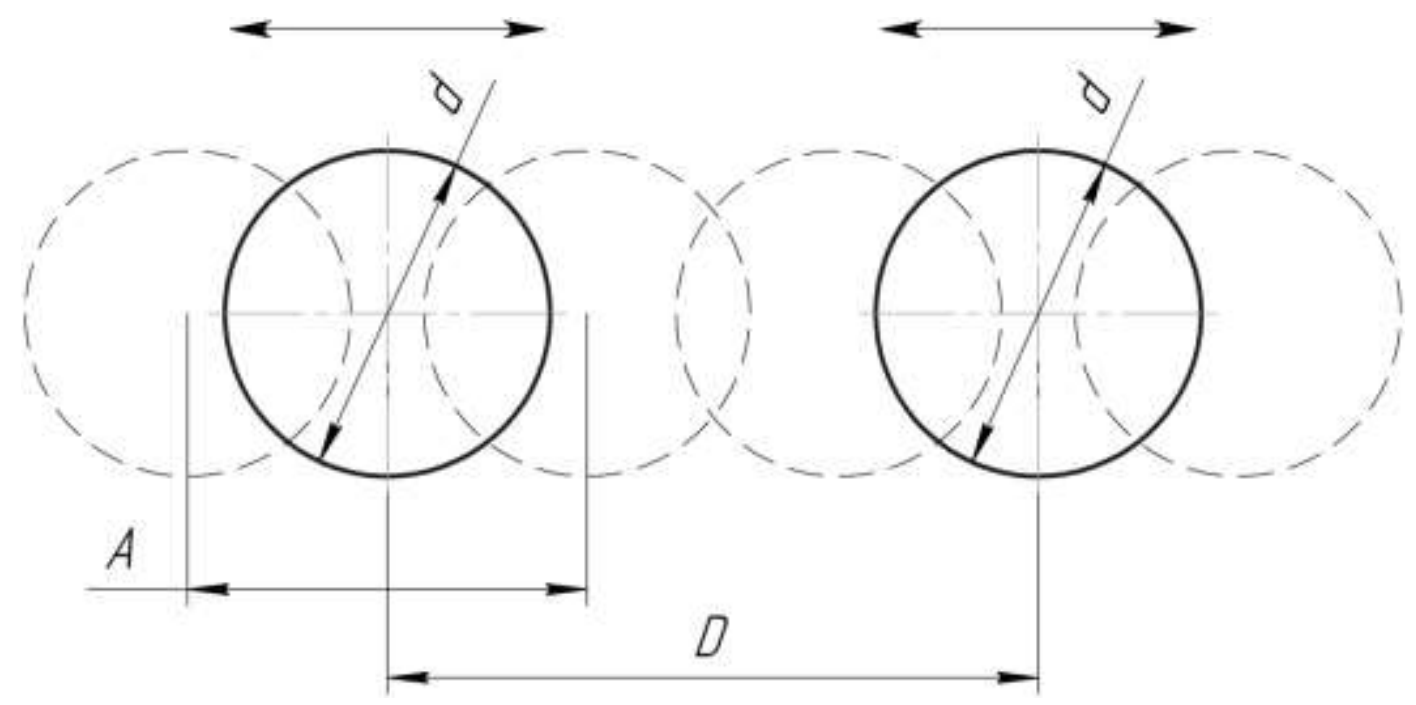

Рис. 1. Схема руху крапель води розміром менше 5 мкм 
Змінюючи параметри зовнішнього поля, можна впливати на частоту та амплітуду коливань мікрокрапель [3, 4], однак для досягнення максимальної продуктивності процесу видалення води 3 робочих рідин потрібно встановлювати раціональні значення параметрів поля для кожного типу оливи та ступеня початкової дисперсності води.

Метою дослідження $\epsilon$ визначення впливу частоти змінного електричного поля на процес коалесценції часток води в РР.

\section{Обладнання}

Ta

методика дослідження. Дослідженням піддавалась емульсія індустріальної оливи И-20 ГОСТ 20799-88 (90 \%) і технічної води (10 \%). Оскільки процес об'єднання крапель довготривалий i не має чіткої грані зупинки, за показовий час був прийнятий час освітлення емульсії.
Обладнання для визначення часу освітлення складається 3 мікроскопа МИМ-7, генератора електричного сигналу високої напруги, секундоміра. Схема розташування проби емульсії та підводу напруги до електродів наведена на рис. 2.

Методика визначення часу освітлення емульсії полягає в наступному. Встановити необхідну частоту коливань та напругу на генераторі частоти 1. На знежирене та висушене тонке скло 3 лабораторної установки помістити одну краплю підготовленої емульсії. Навести фокус окуляра мікроскопа 2 на середину краплі. Одночасно ввімкнути генератор частоти 1 та секундомір. Зафіксувати час освітлення. Занести отримані дані до лабораторного протоколу.

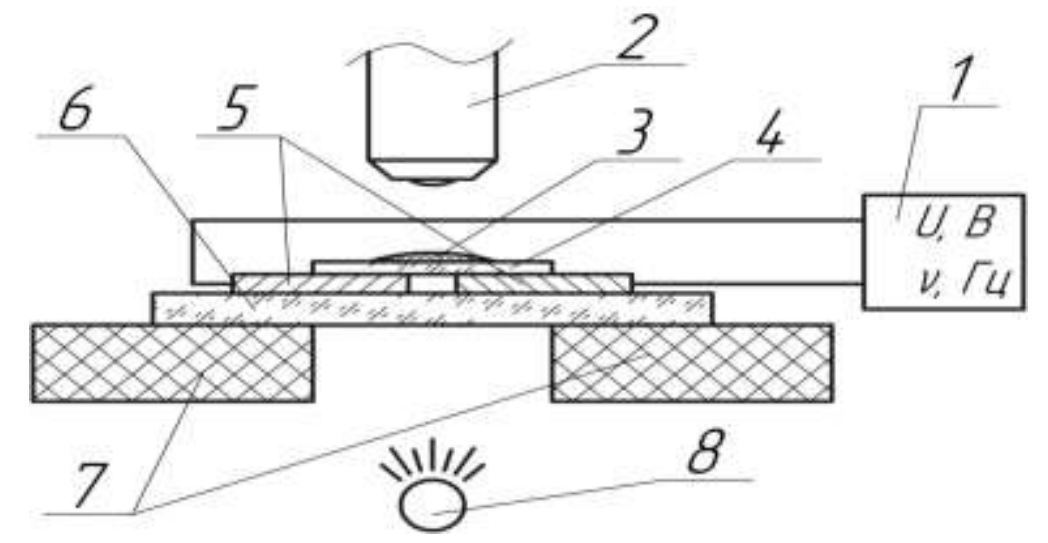

Рис. 2. Схема лабораторної установки:

1 - генератор частоти; 2 - окуляр мікроскопа; 3 - проба емульсії;

4 - тонке скло; 5 - електроди; 6 - предметне скло;

7 - станина мікроскопа; 8 - джерело світла

Обговорення результатів. За отриманими експериментальними даними побудовані рівняння регресії, які відображають зміну часу початку освітлення та часу повного освітлення в діапазоні від 30 Гц до 3 МГц. Рівняння, що описує початок освітлення:

$$
t_{1}=179 v^{-0.21},
$$

рівняння, що описує час повного освітлення:

$$
t_{2}=356 v^{-0.185},
$$

де $t_{1}-$ час початку освітлення, с;

$t_{2}$ - час повного освітлення, с;

$v$ - частота коливання зовнішнього електричного поля, Гц. 
Результати досліджень показують, що частота зовнішнього електричного поля суттєво впливає на процес очищення оливи. На підставі розрахунків отримані графіки зміни часу від частоти поля (рис. 3). Встановлена нелінійна залежність часу освітлення емульсії від частоти. Так при частоті, близькій до 300 Гц, освітлення емульсії починає спостерігатися після $50 \mathrm{c} \mathrm{i}$ триває довгий час (близько 5 хв), а при частоті 3 МГц освітлення починається після 7 с і триває протягом 9 с.

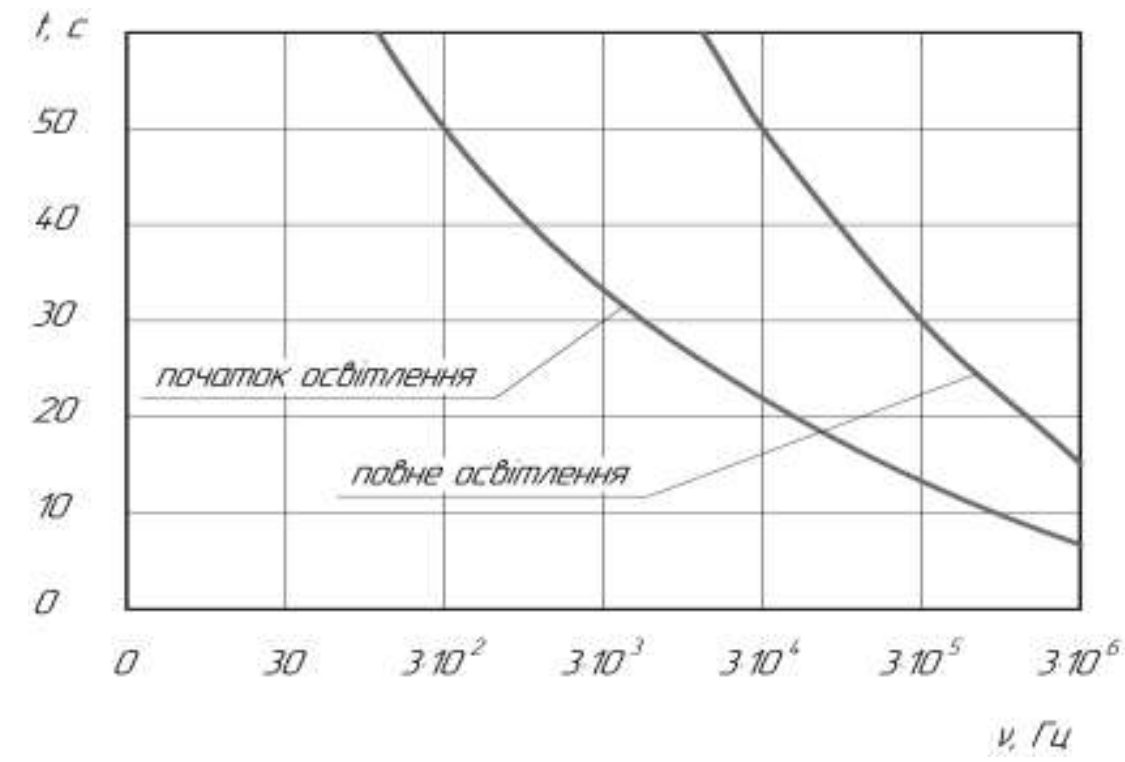

Рис. 3. Залежність часу освітлення емульсії від частоти коливань зовнішнього електричного поля

Такі дані дозволяють встановити швидкість коалесценції води, а також іiі зміну залежно від частоти зовнішнього поля. Наприклад, відносна швидкість коалесценції при частоті 300 кГц складає $0,02 \mathrm{c}^{-1}$, а при частоті 3 МГц $-0,143 \mathrm{c}^{-1}$.

\section{Висновки}

1. Частота електричного поля $\epsilon$ суттєвим фактором, що впливає на процес коалесценції води в РР. Найшвидше такий процес протікає при частотах 1-3 МГц.

2. Отримані експериментальні дані можуть бути використані при розробленні електричного способу очищення РР для гідроприводів машин та інших олив на нафтовій основі. Ключовим питанням залишається досягнення максимальної продуктивності процесу очищення.

\section{Список використаних джерел}

1. John Sander. Water Pollution [Електронний ресурс] / John Sander // Lubrication Engineers International AG. - Режим доступу: http://le-russia.ru/novosti-i-media/zagryaznenie-vodoy

2. Лысиков, Е.Н. Анализ эффективности современных методов очистки жидких смазочных сред на углеводородной основе [Текст] / Е.Н. Лысиков, С.Н. Солонинченко // $3 б$. наук. праць. - Харків6 УкрДАЗТ, 2010. - Вип. 115. - С. 117-121.

3. Панченков, Г.М. Поведение эмульсий во внешнем электрическом поле [Текст] / Г.М. Панченков, Л.К. Цабек. - М.: Химия, 1969. - 190 с. 
4. Мартыненко, А.Г. Очистка нефтепродуктов в электрическом поле постоянного тока [Текст] / А.Г. Мартыненко, В.П. Коноплев, Г.П. Ширяева. - М.: Химия, 1974. - 87 с.

Рецензент д-р техн. наук, професор Н.П. Ремарчук

Воронін Сергій Володимирович, кандидат технічних наук, доцент кафедри будівельних, колійних і вантажнорозвантажувальних машин Української державної академії залізничного транспорту. Тел.:(057) 730-10-66.

E-mail: voronin.sergey@ukr.net

Сафонюк Іван Юрійович аспір. кафедра будівельних, колійних і вантажно-розвантажувальних машин

Української державної академії залізничного транспорту. Тел.: (093)303-31-38. E-mail: jonisaf@meta.ua.

Олійник Андрій Васильович магістрант кафедри будівельних, колійних і вантажно-розвантажувальних машин Української державної академії залізничного транспорту. Тел.: 730-10-72.

Voronin Sergey Volodimirovich, cand. of techn. sciences department of budivelnih, koliynih i vantazhno rozvantazhuvalnih machines Ukraine State Academy of Railway Transpor. Tel. : (057 ) 730-10-66.

E-mail: voronin.sergey @ ukr.net

Safonyuk Ivan Yuriyovich, postgraduate of department budivelnih, koliynih i vantazhno - rozvantazhuvalnih machines Ukraine State Academy of Railway Transport.Tel. : (093 ) 303-31-38.E-mail: jonisaf@meta.ua.

Oliynik Andrij Vasylovych, master student of department budiveln, koliynih i vantazhno - rozvantazhuvalnih machines Ukraine State Academy of Railway Transport. Tel. : 730-10-72 